\title{
Long-term Effect of Winter Gibberellic Acid Sprays and Auxin Applications on Crop Value of 'Clausellina' Satsuma
}

\author{
Amílcar M.M. Duarte1, Amparo García-Luis, Rosa Victoria Molina, Consuelo Monerri, \\ Vicente Navarro, Sergio G. Nebauer, Manuel Sánchez-Perales, and Jose Luis Guardiola ${ }^{2}$ \\ Departamento de Biología Vegetal, Universidad Politécnica de Valencia, 46071-Valencia, Spain
}

\begin{abstract}
AdDitional INDEX WORDs. 2,4-dichlorophenoxyacetic acid, 2,4-dichlorophenoxypropionic acid, Citrus unshiu, flowering, fruit size, fruit quality, naphthaleneacetic acid

ABstract. A winter gibberellic acid (GA G $_{3}$ spray consistently reduced flower formation, but had a variable effect on the amount of first-grade fruit in the early harvest of 'Clausellina' satsuma (Citrus unshiu Marc.), and in the long term these applications had no significant effect on the value of the crop. Auxin applications increased the amount of first grade-early harvested fruit, and increased crop value as compared to hand-thinned trees. No significant differences in yield or fruit grade could be found among the different auxin applications tried, namely an application of $20 \mathrm{mg} \cdot \mathrm{L}^{-1}$ 2,4-dichlorophenoxyacetic acid (2,4-D) at flowering, or applications of $25 \mathrm{mg} \cdot \mathrm{L}^{-1}$ naphthaleneacetic acid (NAA), or 50 $\mathrm{mg} \cdot \mathrm{L}^{-1}$ 2,4-dicholorophenoxypropionic acid (2,4-DP) at the end of fruitlet abscission. Apart from their effect on size, the auxin applications had only a marginal effect on fruit quality.
\end{abstract}

In all the Citrus L. species tested so far, a gibberellic acid $\left(\mathrm{GA}_{3}\right)$ spray during the winter rest period reduced flower formation during the next spring flush of growth (Goldschmidt and Monselise, 1972; Guardiola et al., 1982; Moss, 1970). Since most of the flowers are shed during post-anthesis, this reduction in flower formation decreased significantly the losses through abscission during flowering and set (Guardiola, 1988; Guardiola et al., 1982). This circumstance has been reported to result in a faster early growth of the developing fruitlets and leaves under some conditions (Guardiola et al., 1980). In some cases, this effect on early fruit growth was transient (Guardiola et al., 1980), but a clear benefit on crop value has been also reported. Thus, Guardiola et al. (1984) reported a four-fold increase in yield in high-flowering (and low-yielding) 'Washington navel' orange [C. sinensis (L.) Osbeck] trees. In 'Esbal' clementine (C. clementina Hort. ex Tan.), the reduction in flowering caused by a $\mathrm{GA}_{3}$ application reduced the number of fruit set, but significantly increased fruit size while having no effect on yield (Duarte et al., 1996).

In the present report we analyze the long-term effect of a winter $\mathrm{GA}_{3}$ spray on crop value in 'Clausellina' satsuma. This satsuma cultivar, originated as a natural limb sport on an 'Owari' satsuma tree by the early 1970s in the past century (Guardiola et al., 1973), has some acceptance in Spain because of the earliness of its fruit. Because of the fairly low quality of the fruit, this cultivar is harvested selectively early in the season, before the fruit from other cultivars are marketable, and this first harvest is the main factor to give the cultivar commercial value. 'Clausellina' satsuma trees

Received for publication 15 Dec. 2005. Accepted for publication 22 Mar. 2006. Mr. Francisco Petit performed the orchard applications and coordinated the field work. We thank Mr. Batiste Escutia and the Cooperativa de Alginet (Coagri) for providing the orchard and the packinghouse facilities, respectively, and the R+D+I Linguistic Assistance Office at the Universidad Politécnica of Valencia for their language revision. This research was supported by CICYT (Grant PB95-0736) and the Generalitat Valenciana (Grants GV-CAPA00-11 and Grupos 04/059).

${ }^{1}$ Current address: Faculdade de Engenharia de Recursos Naturais, Universidade do Algarve, Campus de Gambelas, 8000-Faro, Portugal.

${ }^{2}$ Corresponding author; phone: +34.963877411 ; fax: +34.963877419 ; e-mail: jlguardiola@bvg.upv.es are characterized by having low vigor, thus requiring pruning every year in order to invigorate the tree and to obtain a regular yield (Zaragoza et al., 1990). A beneficial effect could therefore be expected from a winter $\mathrm{GA}_{3}$ spray. We have also studied the combined effects of the winter $\mathrm{GA}_{3}$ sprays with that of auxin applications. This cultivar usually sets a high number of small fruit, which forces growers to thin the trees, either manually (Zaragoza et al., 1990) or chemically (Agustí et al., 1994).

\section{Materials and Methods}

The experiments were performed in a high density orchard (1430 trees/ha) of 10-year-old 'Clausellina' satsuma trees grafted onto Carrizo citrange (C. sinensis $\times$ Poncirus trifoliata Raf.) rootstock, growing in a sandy clay soil with flood irrigation. The trees were pruned every year. A split-plot design was followed, with the auxin applications as the main factor and the application of $\mathrm{GA}_{3}$ during winter as a covariate. The auxin applications followed a $4 \times 4$ lattice design, each replicate having 24 trees in two parallel rows. The trees in one of the two rows were sprayed on 15 Dec. with a $20 \mathrm{mg} \cdot \mathrm{L}^{-1} \mathrm{GA}_{3}$ solution. The auxin applications were: 1) none (hand-thinned control trees); 2$) 2,4-\mathrm{D}\left(20 \mathrm{mg} \cdot \mathrm{L}^{-1}\right.$ as isopropyl ester) sprayed at full bloom; 3$)$ NAA $\left(25 \mathrm{mg} \cdot \mathrm{L}^{-1}\right.$ as ethylamine salt) sprayed shortly before the end of fruitlet abscission, when the developing fruitlets were 10 to $15 \mathrm{~mm}$ in diameter; and 4) 2,4-DP (50 $\mathrm{mg} \cdot \mathrm{L}^{-1}$ as ethylglycol ester) sprayed at the same date as for NAA. Due to the differences in development, the date of the auxin applications varied slightly from year to year, from 22 Apr. to 6 May (full bloom applications) and from 18 to 31 May (applications at the end of abscission). A non-ionic wetting agent (alkylpolyglycol ether) at $0.01 \%$ was added to all spray solutions. The amount sprayed per tree ranged between 2.7 and 3.2 L. Hand thinning was accomplished by removing fruit less than $30 \mathrm{~mm}$ in diameter shortly after the June drop (in early August). The intensity of the thinning process was monitored 1 year counting the number of fruit removed. It ranged between $19 \%$ and $30 \%$ of the fruit present on the tree, with an average value of $23 \%$. The experiment was repeated during four consecutive years. The same 
treatments were performed on the same trees every year, in order to determine the long-term effects of each treatment.

Selective harvesting based on rind color was performed simultaneously in all treatments, at the time about half of the fruit had reached a color index higher than -10 according to the scale developed by Jiménez-Cuesta et al. (1981). At this stage the fruit becomes sensitive to degreening with ethylene. The date at which this color index value was reached varied from year to year, from 18 Sept. to 4 Oct. All the fruit that had reached this color index and were of a marketable size were harvested. On each replicate, the fruit were weighed, counted, and separated into size classes in a belt-and-roll sizer in a packing-house, according to the standards set by the Organisation de Coopération et Développement Économique (OCDE, 1971). The fruit belonging to size classes 2 (58 to $63 \mathrm{~mm}$ in diameter) and $1 \mathrm{x}$ (63 to $71 \mathrm{~mm}$ ) were considered in this study as first-grade fruit, as their market price was several-fold higher than the rest of the fruit.

The fruit left behind on the tree after the selective harvesting, were harvested, counted, and weighed 3-4 weeks later. Using these values, the total harvest per tree and the average fruit weight were calculated.

In the first 3 years of the experiment (years 1 to 3 ), random samples consisting of 20 size- 2 fruit from the selective picking were taken from each replicate. These samples were used for the determination of the fruit characteristics. Fruit weight, peel weight and thickness, juice contents of the fruit, and the total soluble solids concentration (TSS) and titratable acidity (TA) of the juice were measured as described by Ortolá et al. (1991).

The effect of the winter $\mathrm{GA}_{3}$ spray on flowering was measured during years 2 and 4 . Before the onset of bud sprouting, four branches orthogonally oriented and with more than 200 nodes were marked on each of $20 \mathrm{GA}_{3}$-treated trees and 20 untreated controls chosen at random. The percentage of bud sprouting, and the number of vegetative shoots, leafy inflorescences, and leafless inflorescences were measured by the end of March, shortly before anthesis. The results were expressed as the number of shoots developed per 100 nodes to compensate for the differences in size of the selected branches. Flower and inflorescence characteristics were determined in random samples of 100 inflorescences.

The significance of the treatment effects on the main parameters was determined by means of an analysis of variance (ANOVA). When significant differences were found, the values of the auxin treatments were compared according to Duncan's multiple range test. Simple regression analysis was performed to determine the relationship between parameters. The statistical package Statgraphics plus 5.1 (Statistical Graphics Corp., Herndon, Va.) was used for the calculations.

\section{Results}

EFFECTS OF A WINTER GA 3 SPRAY ON FLOWERING AND SHOOT DEVELOPMENT. A winter $\mathrm{GA}_{3}$ spray consistently reduced the number of leafless inflorescences formed in spring (Table 1). In year 2 it also reduced both the percentage of bud sprouting and the total number of shoots developed during the spring flush (Table 1). This effect was not found in year 4 . There was no consistent effect on the number of vegetative shoots formed, which increased as a result of the $\mathrm{GA}_{3}$ application in year 2, but not in year 4 (Table 1 ). The $\mathrm{GA}_{3}$ applications had no significant effect on the number of leafy inflorescences, nor in pistil weight at anthesis (Table 1).

There were significant differences in the effect of the $\mathrm{GA}_{3}$ application on the vigor of the developing shoots in the 2 years. In year 2, the $\mathrm{GA}_{3}$ application increased the weight of the stem both in the vegetative shoots and in the inflorescences (Table 2). In the vegetative shoots, stem length and leaf number also were increased by the application. These two effects were not observed in the inflorescences, in which there was an increase in average leaf weight instead (Table 2). As a consequence, there was an increase in total shoot weight both in the inflorescences $(P \leq 0.05)$ and in the vegetative shoots $(P \leq 0.10)$ formed during the spring flush (Table 2). In year 4 , the $\mathrm{GA}_{3}$ application did not increase the weight or the length of the stem, nor the number of leaves of the developing shoots. Average leaf weight (and size) decreased both in the vegetative shoots and in the inflorescences (Table 2), but total shoot weight was not affected significantly. In the 2 years, there was a change in weight allocation in the vegetative shoots, with a significant $(P \leq 0.05)$ reduction in the proportion of leaf to total shoot weight. This value went down from $86.6 \%$ to $84.7 \%$

Table 1. The effect of a winter $\mathrm{GA}_{3}$ spray on bud sprouting and flower formation and characteristics in 'Clausellina' satsuma trees. $\mathrm{GA}_{3}(20$ $\left.\mathrm{mg} \cdot \mathrm{L}^{-1}\right)$ was sprayed on 15 Dec. Shoot counts and flower sampling were performed at flowering (6 May in year 2 and 24 Apr. in year 4). Data from 2 years.

\begin{tabular}{|c|c|c|c|c|}
\hline \multirow[b]{2}{*}{ Parameter } & \multicolumn{2}{|c|}{ Year 2} & \multicolumn{2}{|c|}{ Year 4} \\
\hline & Untreated & $\begin{array}{c}\mathrm{GA}_{3}^{-} \\
\text {treated }^{z}\end{array}$ & Untreated & $\begin{array}{c}\mathrm{GA}_{3^{-}} \\
\text {treated }\end{array}$ \\
\hline$\overline{\text { Bud sprouting (\%) }}$ & 73 & $51^{*}$ & 60 & 56 \\
\hline Shoots (no./100 nodes) & 108 & $64^{*}$ & 84 & 76 \\
\hline Vegetative & 5 & $20^{*}$ & 13 & 17 \\
\hline Leafy inflorescences & 14 & 12 & 18 & 23 \\
\hline Leafless inflorescences & 89 & $32 *$ & 53 & $34^{*}$ \\
\hline Pistil wt (mg)y & 100 & 103 & 96 & 95 \\
\hline
\end{tabular}

zValues with an asterisk $(*)$ differ significantly at $P \leq 0.05$ from the untreated control of the same year ( $t$ test comparison).

yFrom leafy inflorescences.

Table 2. The influence of a winter $\mathrm{GA}_{3}$ spray on the characteristics of the shoots developed in 'Clausellina' trees during the spring flush of growth. $\mathrm{GA}_{3}\left(20 \mathrm{mg} \cdot \mathrm{L}^{-1}\right)$ was sprayed on $15 \mathrm{Dec}$. Shoot samples of vegetative sprouts and unifloral leafy inflorescences (100 shoots each sample picked at random from 10 trees) were picked on 6 May (year 2) and 7 Apr. (year 4). Values are the means of 100 shoots sampled at random.

\begin{tabular}{|c|c|c|c|c|c|c|}
\hline \multirow{2}{*}{$\begin{array}{l}\text { Year, date of } \\
\text { sampling, and } \\
\text { type of shoot }\end{array}$} & \multirow{2}{*}{$\begin{array}{l}\text { Shoot } \\
\text { length } \\
(\mathrm{cm})\end{array}$} & \multirow{2}{*}{$\begin{array}{c}\text { Leaves } \\
\text { (no./ } \\
\text { shoot) }\end{array}$} & \multirow{2}{*}{$\begin{array}{l}\text { Avg } \\
\text { leaf } \\
\text { wt }(g)\end{array}$} & \multicolumn{3}{|c|}{ Shoot fresh wt $(\mathrm{g})$} \\
\hline & & & & Leaves & Stem & Total \\
\hline \multicolumn{7}{|l|}{ Year 2 (6 May) } \\
\hline \multicolumn{7}{|l|}{ Vegetative } \\
\hline Untreated & 8.3 & 5.4 & 0.60 & 3.3 & 0.51 & 3.8 \\
\hline $\mathrm{GA}_{3}$-treated & $11.2^{*}$ & $6.6^{*}$ & $0.55^{\mathrm{NS}}$ & $3.6^{\mathrm{NS}}$ & $0.65^{*}$ & $4.2^{\dagger}$ \\
\hline \multicolumn{7}{|l|}{ Inflorescence } \\
\hline Untreated & 6.5 & 4.9 & 0.41 & 2.0 & 0.28 & 2.3 \\
\hline $\mathrm{GA}_{3}$-treated & $7.1^{\mathrm{NS}}$ & $5.0^{\mathrm{NS}}$ & $0.48^{*}$ & $2.4^{*}$ & $0.33^{*}$ & $2.8^{*}$ \\
\hline \multicolumn{7}{|l|}{ Year 4 (7 Apr.) } \\
\hline \multicolumn{7}{|l|}{ Vegetative } \\
\hline Untreated & 15.3 & 8.9 & 0.21 & 1.9 & 0.78 & 2.6 \\
\hline $\mathrm{GA}_{3}$-treated & $15.2^{\mathrm{NS}}$ & $8.0^{\mathrm{NS}}$ & $0.18^{*}$ & $1.5^{*}$ & $0.79^{\mathrm{NS}}$ & $2.3^{\mathrm{NS}}$ \\
\hline \multicolumn{7}{|l|}{ Inflorescence } \\
\hline Untreated & 2.6 & 3.0 & 0.32 & 1.0 & 0.11 & 1.1 \\
\hline $\mathrm{GA}_{3}$-treated & $2.6^{\mathrm{NS}}$ & $3.2^{\mathrm{NS}}$ & $0.27 *$ & $0.9^{\mathrm{NS}}$ & $0.11^{\mathrm{NS}}$ & $1.0^{\mathrm{NS}}$ \\
\hline
\end{tabular}

$\mathrm{ss},+, *$ Nonsignificant or significant from the untreated trees according to the $t$ test at $P \leq 0.10$ or 0.05 , respectively. 


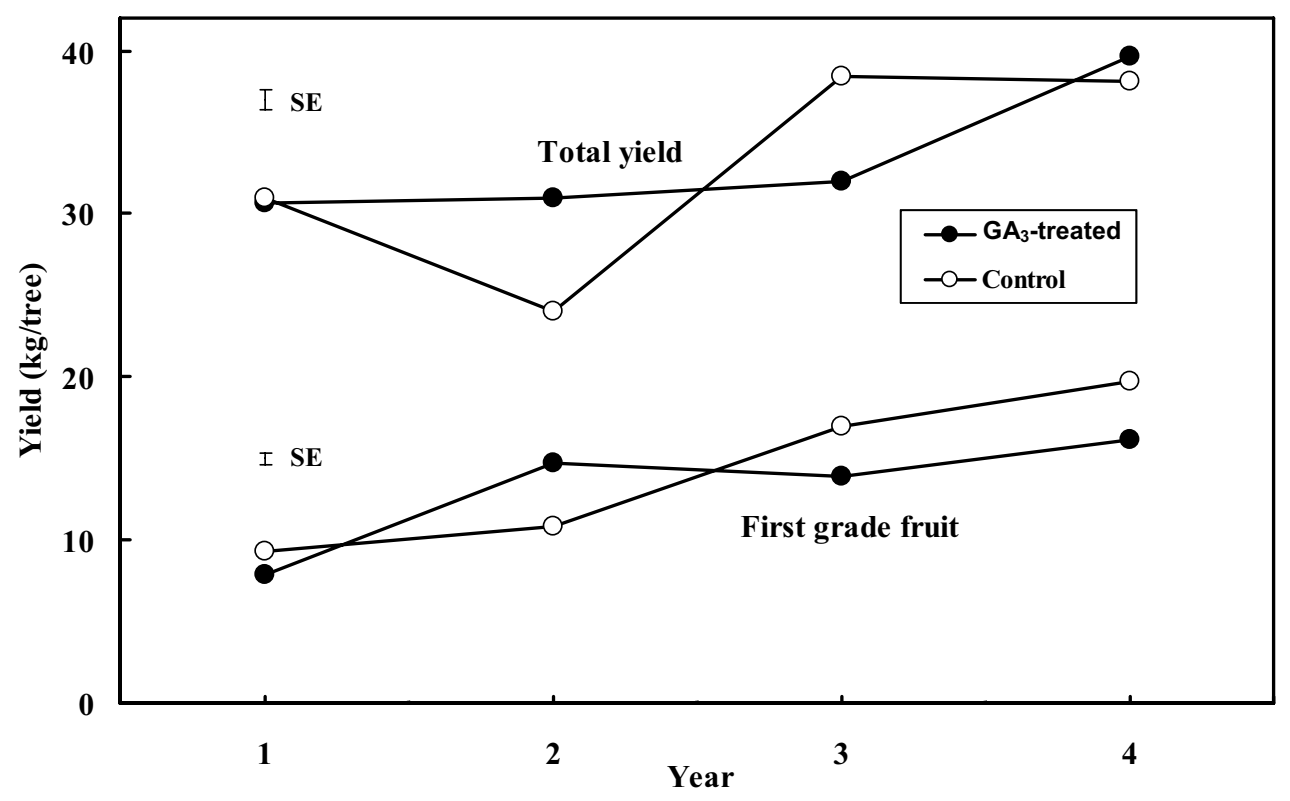

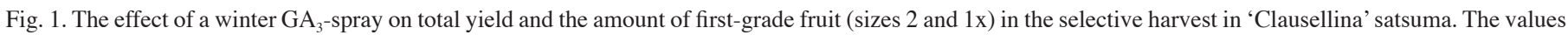
are averages of the four auxin treatments. The bars indicate SE.

in year 2 , and from $73.0 \%$ to $65.2 \%$ in year 4 . This reduction did not occur in the inflorescences (data not shown).

YIELD AND ITS COMPONENTS. As shown in Fig. 1, total yield, for the yearly average of the $\mathrm{GA}_{3}$ treatments, ranged from 27.4 $\mathrm{kg} /$ tree (untreated trees; year 2) to $38.9 \mathrm{~kg} /$ tree $\left(\mathrm{GA}_{3}\right.$-treated trees, year 4). This year-to-year variation accounted for $35.9 \%$ of the total variability in yield (Table 3 ), and explained $60.6 \%$ of the total effect of the controlled factors on this parameter (calculated as the ratio between the year effect (35.9) and the sum (59.2) of the effects of all the controlled parameters and their first order interactions). Yield was mainly determined by fruit number (Fig. 2 ), as indicated by the strong linear relationship between these two parameters $\left(r^{2}=0.761, P \leq 0.01\right)$. A significant departure from linearity occurred when fruit number dropped below 200 (Fig. 2), where a logarithmic curve fitted significantly better (evidence not presented). On the other hand, average fruit weight was inversely related to fruit number (Fig. 3). The comparison of the regression lines for the different years demonstrated significant differences in the intercept (evidence not presented). When adjusted to fruit number, both total yield and average fruit weight were smaller than predicted by the regression lines (calculated with the combined data from the 4 years) in year 1, and bigger in year 3 (Figs. 2 and 3 ). The multiple regression analysis (not shown) demonstrated that the combined effect of fruit number and year-to-year variation was the main determinant of these parameters, as it explained $85 \%$ of the total variability in fruit size, and $91 \%$ of the variability in total yield. Average fruit weight was weakly $\left(r^{2}=0.149\right)$ but significantly $(P \leq 0.01)$ inversely related to total yield.

There was a weak linear positive correlation between selective harvest and total yield $\left(r^{2}=0.384, P \leq 0.01\right)$. The selective harvest, as a percentage of total yield, ranged between 53\% (year 1) and $67 \%$ (year 4 ). This year-to-year variation only explained $14.3 \%$ of the total variability in this percentage (Table 3).

EFFECTS OF $\mathbf{G A}_{3}$ ON YIELD. The effect of the $\mathrm{GA}_{3}$ sprays on total yield was rather weak, and varied from year to year as indicated by the significant interaction of the effects of these two factors in the ANOVA (Table 3). As compared to the controls,
Table 3. The effect of auxin and winter $\mathrm{GA}_{3}$ applications on total yield, the number of fruit per tree, and average fruit weight in 'Clausellina' satsuma. The $\mathrm{GA}_{3}$ applications $\left(20 \mathrm{mg} \cdot \mathrm{L}^{-1}\right)$ were performed on 15 Dec. The auxin applications were performed at anthesis $\left(20 \mathrm{mg} \cdot \mathrm{L}^{-1}\right.$ 2,4-D) or at the end of June drop ( $25 \mathrm{mg} \cdot \mathrm{L}^{-1} \mathrm{NAA}$ or $50 \mathrm{mg} \cdot \mathrm{L}^{-1} 2,4-$ DP). A selective harvest was performed when $50 \%$ to $60 \%$ of the fruit had reached a color index higher than -10 . Values are the means of 4 years of experimentation.

\begin{tabular}{|c|c|c|c|c|}
\hline Treatment $^{z}$ & $\begin{array}{c}\text { Total } \\
\text { yield } \\
\text { (kg/tree) }\end{array}$ & $\begin{array}{c}\text { Fruit } \\
\text { (no./tree) }\end{array}$ & $\begin{array}{c}\text { Avg } \\
\text { fruit } \\
\text { wt (g) }\end{array}$ & $\begin{array}{c}\text { Selective } \\
\text { harvest } \\
\text { (\% of total } \\
\text { harvest) }\end{array}$ \\
\hline \multicolumn{5}{|l|}{$\overline{\mathrm{GA}_{3} \text { effect }}$} \\
\hline Untreated (control) & 32.9 & 382 & 88.9 & $62.5 \mathrm{a}$ \\
\hline $\mathrm{GA}_{3}$-treated & 33.2 & 394 & 87.2 & $58.1 \mathrm{~b}$ \\
\hline SE & 0.66 & 9.0 & 0.76 & 1.5 \\
\hline \multicolumn{5}{|l|}{ Auxin effect } \\
\hline No auxin (hand-thinned) & 32.3 & 397 & $84.0 \mathrm{a}$ & $54.1 \mathrm{a}$ \\
\hline $2,4-\mathrm{D}$ & 34.1 & 398 & $87.9 \mathrm{~b}$ & $58.5 \mathrm{ab}$ \\
\hline 2,4-DP & 32.1 & 363 & $91.3 \mathrm{c}$ & $67.0 \mathrm{c}$ \\
\hline NAA & 33.5 & 392 & $89.0 \mathrm{bc}$ & $61.5 \mathrm{bc}$ \\
\hline $\mathrm{SE}$ & 0.94 & 18.0 & 1.1 & 2.1 \\
\hline
\end{tabular}

Analysis of variance

Parameter (df)

Year $(\mathrm{n}=3)$

----Proportion of total sum of squares (\%) ----

$35.9^{* *}-44.7^{* *} \quad 65.6^{* *} \quad 14.3^{* * *}$

$\mathrm{GA}_{3}$ application $(\mathrm{n}=1) \quad 0.05^{\mathrm{NS}} \quad 3.00^{\mathrm{NS}} \quad 0.38^{\mathrm{NS}} \quad 2.4^{*}$

Auxin applications $(\mathrm{n}=3) \quad 1.30^{\mathrm{NS}} \quad 1.59^{\mathrm{NS}} \quad 4.08^{* *} \quad 33.4^{* *}$

Year $\times \mathrm{GA}_{3}$

application $(\mathrm{n}=3) \quad 11.2^{* *} \quad 10.6^{* *} \quad 6.17^{* *} \quad 4.0^{\dagger}$

Year $x$ auxin

applications $(\mathrm{n}=9) \quad 9.65^{* *} \quad 8.60^{* *} \quad 5.12^{* *} \quad 10.6^{* *}$

$\mathrm{GA}_{3} \times$ auxin

applications $(\mathrm{n}=3) \quad 1.11^{\mathrm{NS}} \quad 0.53^{\mathrm{NS}} \quad 0.63^{\mathrm{NS}} \quad 2.1^{\mathrm{NS}}$

${ }^{z}$ Values within a column with different letters are statistically different $(P \leq 0.05)$.

NS, $+, *, * *$ Nonsignificant or significant at $P \leq 0.10,0.05$, or 0.01 , respectively. 


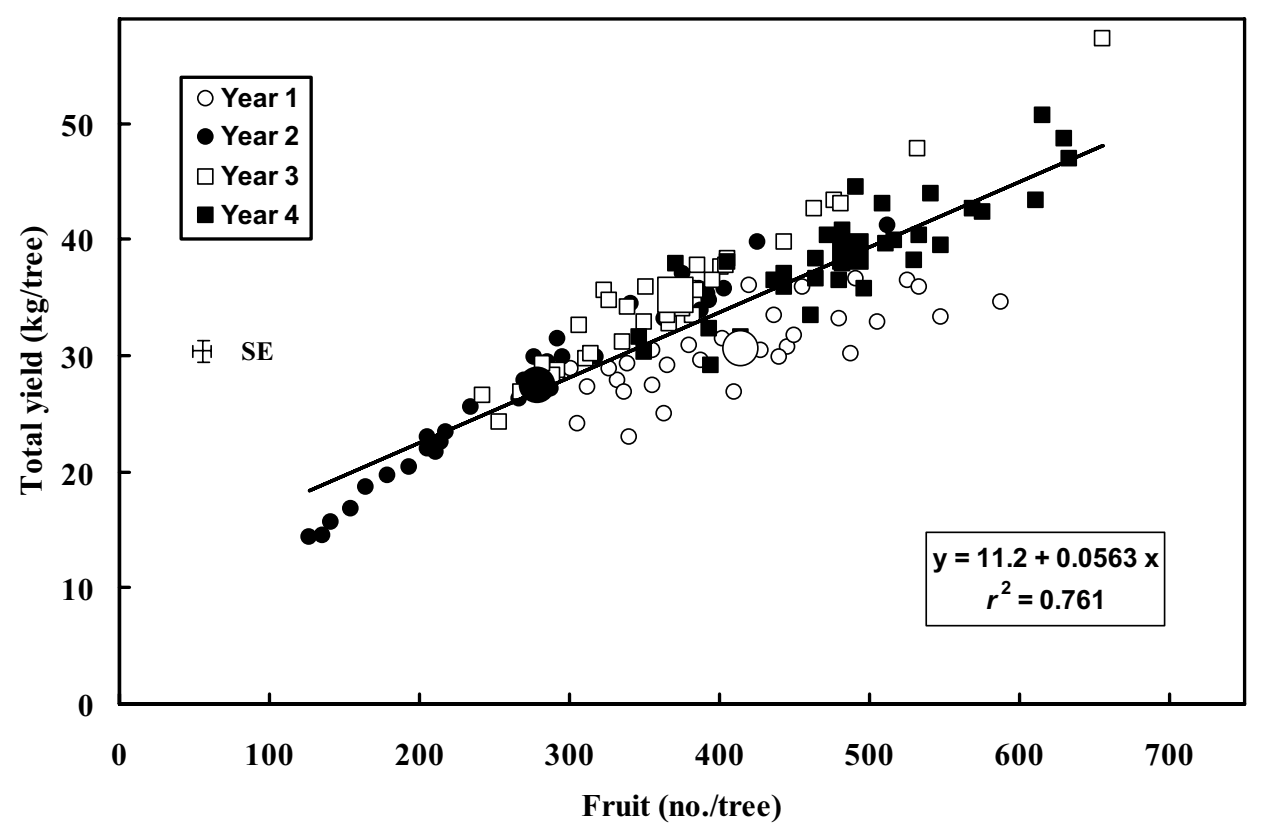

Fig. 2. The relationship between total yield and the number of fruit per tree in 'Clausellina' satsuma trees. The points (128) are the values of every replicate (four) of the 32 auxin (four treatments) $\times \mathrm{GA}_{3}$ (two treatments) $\times$ year $(4$ years) combinations. The big size symbols are the means for all treatments each experimentation year; the bars indicate SE.

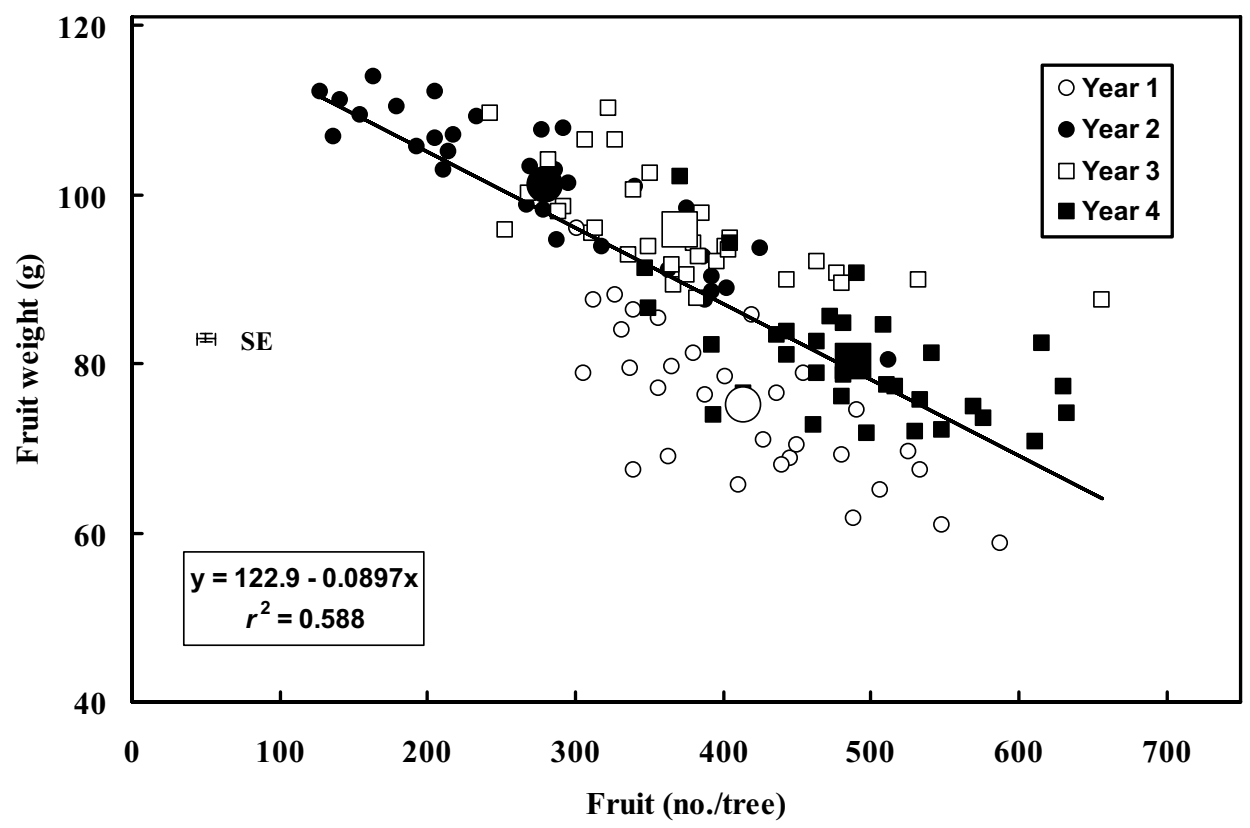

Fig. 3. The relationship between average fruit weight and the number of fruit per tree in 'Clausellina' satsuma trees. The points (128) are the value of every replicate (four) of the 32 auxin (four treatments) $\times \mathrm{GA}_{3}$ (two treatments) $\times$ year (4 years) combinations. The big size symbols are the means for all treatments each experimentation year; the bars indicate sE.

the application of $\mathrm{GA}_{3}$ increased yield in year 2, but reduced it in year 3 (Fig. 1). In the 4-year average, $\mathrm{GA}_{3}$ showed no significant effect on total yield (Table 3 ).

The application of $\mathrm{GA}_{3}$ reduced slightly, albeit significantly, the percentage of fruit in the selective harvest, from $62.5 \%$ in the untreated to $58.1 \%$ in the $\mathrm{GA}_{3}$-treated trees (Table 3 ). The combination of these two effects resulted in a reduction of firstgrade fruit by $\mathrm{GA}_{3}$ in years 3 and 4 , and an increase in year 2 (Fig. 1).
EFFeCtS OF AUXIN APPLICATIONS ON YIELD. The total number of fruit harvested after auxin applications were not significantly different than the hand-thinned controls (Table 3). Since the untreated control trees were hand-thinned removing $23 \%$ of the developing fruit (see Materials and Methods section), this means that the auxin applications had a significant thinning effect. The number of fruit harvested was slightly smaller in the 2,4-DP treatment, but this effect was not statistically significant. Average fruit weight increased with all the auxin applications compared to the 
hand-thinned control. This parameter was slightly higher in the 2,4-DP than in the 2,4-D treatment (Table 3). Despite this increase in average fruit weight, the differences in total yield among auxin treatments for the average of the 4 years of experimentation, did not reach statistical significance (Table 3 ). However, the separate study of this parameter in the different years revealed differences in the response to the auxin applications, as indicated by the significant interaction in the ANOVA (Table 3). In year 2, the application of either NAA or 2,4-DP reduced both fruit number and yield as compared to 2,4-D and the hand-thinned controls. In year 3, both 2,4-D and NAA applications resulted in an increase in yield over the hand-thinned controls (data not shown).

The auxin applications increased both the percentage of fruit in the selective harvest (Table 3 ) and the amount of first-grade fruit (Tables 4 and 5). The amount of first-grade fruit with the auxin applications was on average $18 \%$ higher than the hand-thinned

Table 4. Analysis of the variance for the effect of auxin and winter $\mathrm{GA}_{3}$ applications on the amount of first-grade fruit $(58-71 \mathrm{~mm}$ in diameter) in the selective harvest in 'Clausellina' satsuma. The $\mathrm{GA}_{3}$ applications $\left(20 \mathrm{mg} \cdot \mathrm{L}^{-1}\right)$ were performed on $15 \mathrm{Dec}$. The auxin applications were performed at anthesis $\left(20 \mathrm{mg} \cdot \mathrm{L}^{-1} 2,4-\mathrm{D}\right)$ or at the end of June drop ( $25 \mathrm{mg} \cdot \mathrm{L}^{-1} \mathrm{NAA}$ or $\left.50 \mathrm{mg} \cdot \mathrm{L}^{-1} 2,4-\mathrm{DP}\right)$. A selective harvest was performed when $50 \%$ to $60 \%$ of the fruit had reached a color index higher than -10 .

\begin{tabular}{lccc}
\hline & $\begin{array}{c}\text { Proportion of total } \\
\text { sum of squares (\%) }\end{array}$ & F ratio & $P$ \\
\hline Year (3) & 38.2 & 26.9 & $<0.001$ \\
GA $_{3}$ application (1) & 0.9 & 1.9 & NS \\
Auxin applications (3) & 2.9 & & \\
No auxin vs. auxin-treated (1) & 2.6 & 5.5 & $<0.01$ \\
Among auxin applications (2) & 0.3 & 0.6 & NS \\
Year $\times$ GA $_{3}$ application (3) & 6.9 & 4.9 & $<0.01$ \\
Year $\times$ auxin applications (9) & 2.6 & 0.6 & NS \\
GA $_{3}$ application $\times$ auxin & & & \\
$\quad$ applications (3) & 1.2 & 0.8 & NS \\
Second order interaction (9) & 2.0 & 0.5 & NS \\
Residual (96) & 45.4 & & \\
\hline
\end{tabular}

controls. No significant difference was found among the three auxin applications (Table 5). In the auxin treatments, first-grade fruit represented $42.6 \%$ of the total harvest, while in the hand-thinned trees it was only $37.5 \%$. The slightly higher average fruit weight in the 2,4-DP application (Table 3 ) resulted in an increase in the number of oversized fruit (culls, Table 5), but did not increase significantly the amount of first-grade fruit as compared to the other auxin applications (Table 5). The increase in the number of culls caused by the application of NAA and 2,4-D was significantly smaller than in the 2,4-DP treatment (Table 5).

GA AFFECT ON FRUIT QUALITY. GA $_{3}$ had no effect on the weight of the fruit parts (peel and segments) or on juice percentage (Table 6). The most consistent effect of $\mathrm{GA}_{3}$ on fruit quality was an increase in acidity (Table 7), which resulted in a significant reduction in the TSS : TA ratio (Table 7). No significant effect of $\mathrm{GA}_{3}$ on TSS was observed (Table 7).

Table 5. The effect of auxin applications on first-grade fruit (fruit having an equatorial diameter between 58 and $71 \mathrm{~mm}$, corresponding to the classes 2 and $1 \mathrm{x}$ according to the normative by Organisation de Coopération et Développement Économique), culls (fruit having an equatorial diameter $>71 \mathrm{~mm}$ ), and total fruit $>58 \mathrm{~mm}$ diameter, in the selective harvest in 'Clausellina' satsuma. The selective harvest was performed simultaneously in all treatments, at a time about half of the fruit had reached a color index higher than -10 . Data are the mean of 4 years.

\begin{tabular}{lccc}
\hline Auxin application & $\begin{array}{c}\text { First-grade fruit } \\
(\mathrm{kg} / \text { tree })\end{array}$ & $\begin{array}{c}\text { Culls } \\
(\mathrm{kg} / \mathrm{tree})\end{array}$ & $\begin{array}{c}\text { Total fruit } \\
(\mathrm{kg} / \text { tree })\end{array}$ \\
\hline No auxin (hand-thinned) & $12.1 \mathrm{a}^{\mathrm{z}}$ & $1.1 \mathrm{a}$ & $13.1 \mathrm{a}$ \\
2,4-D & $13.9 \mathrm{~b}$ & $2.1 \mathrm{~b}$ & $15.9 \mathrm{~b}$ \\
2,4-DP & $14.7 \mathrm{~b}$ & $3.5 \mathrm{c}$ & $18.0 \mathrm{~b}$ \\
NAA & $14.0 \mathrm{~b}$ & $2.1 \mathrm{~b}$ & $15.9 \mathrm{~b}$ \\
Significance (F-test) & $* *$ & $* *$ & $* *$ \\
SE & 0.7 & 0.2 & 0.9
\end{tabular}

$\bar{z}$ Values within a column with different letters are statistically different $(P \leq 0.05)$

**Significant at $P \leq 0.01$

Table 6. The effect of $\mathrm{GA}_{3}$ and auxin applications on the characteristics of size 2 fruit (58-63 mm diameter) in the selective harvest in 'Clausellina' satsuma. The selective harvest was performed at the same time for all treatments, at a time about half of the fruit had reached a color index higher than -10 . Values are the means of 3 years ( 1 to 3 ).

\begin{tabular}{|c|c|c|c|c|c|c|}
\hline \multirow[b]{2}{*}{ Treatment $^{z}$} & \multirow[b]{2}{*}{$\begin{array}{l}\text { Fruit wt } \\
\qquad(\mathrm{g})\end{array}$} & \multirow[b]{2}{*}{$\begin{array}{l}\text { Peel wt } \\
\text { (g) }\end{array}$} & \multirow[b]{2}{*}{$\begin{array}{c}\text { Peel thickness } \\
(\mathrm{mm})\end{array}$} & \multirow[b]{2}{*}{$\begin{array}{c}\text { Segment wt } \\
(\mathrm{g})\end{array}$} & \multicolumn{2}{|c|}{ Juice (\% wt basis) } \\
\hline & & & & & $\begin{array}{l}\text { On fruit } \\
\text { basis }\end{array}$ & $\begin{array}{l}\text { On segment } \\
\text { basis }\end{array}$ \\
\hline \multicolumn{7}{|l|}{$\overline{\mathrm{GA}_{3} \text { effect }}$} \\
\hline Untreated & 90.0 & 20.0 & 2.21 & 70.1 & 53.4 & 68.7 \\
\hline $\mathrm{GA}_{3}$-treated & 90.4 & 20.1 & 2.24 & 70.3 & 53.9 & 69.2 \\
\hline \multicolumn{7}{|l|}{ Auxin effect } \\
\hline No auxin (hand-thinned) & 89.3 & $20.4 \mathrm{a}$ & $2.32 \mathrm{a}$ & $68.9 \mathrm{a}$ & $53.9 \mathrm{~b}$ & $69.9 \mathrm{~b}$ \\
\hline $2,4-\mathrm{D}$ & 89.5 & $20.9 \mathrm{a}$ & $2.34 \mathrm{a}$ & $68.6 \mathrm{a}$ & $52.5 \mathrm{a}$ & $68.5 \mathrm{ab}$ \\
\hline 2,4-DP & 91.1 & $19.4 \mathrm{~b}$ & $2.08 \mathrm{~b}$ & $71.8 \mathrm{~b}$ & $53.6 \mathrm{ab}$ & $68.0 \mathrm{a}$ \\
\hline NAA & 90.9 & $19.6 \mathrm{~b}$ & $2.17 \mathrm{~b}$ & $71.4 \mathrm{~b}$ & $54.6 \mathrm{~b}$ & $69.6 \mathrm{~b}$ \\
\hline \multicolumn{7}{|l|}{ Analysis of variance } \\
\hline Parameter (df) & 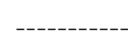 & ------ & -- Proportion of & al sum of squa & --------- & ---------- \\
\hline Year $(n=2)$ & $37.6^{* *}$ & $1.0^{\mathrm{NS}}$ & $1.0^{\mathrm{NS}}$ & $33.9^{* *}$ & $22.3^{* *}$ & $15.7^{* * *}$ \\
\hline $\mathrm{GA}_{3}$ application $(\mathrm{n}=1)$ & $0.1^{\mathrm{NS}}$ & $0.2^{\mathrm{NS}}$ & $0.5^{\mathrm{NS}}$ & $0.0^{\mathrm{NS}}$ & $0.7^{\mathrm{NS}}$ & $1.0^{\mathrm{NS}}$ \\
\hline Auxin application $(n=3)$ & $3.5^{\mathrm{NS}}$ & $21.1^{* *}$ & $26.8^{* *}$ & $10.6^{* *}$ & $8.5^{* *}$ & $6.7^{*}$ \\
\hline Residual $(n=72)$ & 40.9 & 64.6 & 55.8 & 39.0 & 53.5 & 60.2 \\
\hline
\end{tabular}

zValues within a column with different letters are statistically different $(P \leq 0.05)$

Ns, *, **Nonsignificant or significant at $P \leq 0.05$ or 0.01 , respectively. 
Table 7. The effect of $\mathrm{GA}_{3}$ and auxin applications on the total soluble solids (TSS) as determined by refractometry, titratable acidity (TA), and the TSS : TA ratio of the juice from size 2 fruit $(58-63 \mathrm{~mm}$ diameter) in the selective harvest in 'Clausellina' satsuma. Values are the means of 3 years (1 to 3 ).

\begin{tabular}{|c|c|c|c|}
\hline Treatment ${ }^{z}$ & $\begin{array}{l}\text { TSS } \\
(\%)\end{array}$ & $\begin{array}{c}\text { TA } \\
\left(\mathrm{mg} \cdot \mathrm{L}^{-1}\right)\end{array}$ & $\begin{array}{c}\text { TSS:TA } \\
\text { (ratio) }\end{array}$ \\
\hline \multicolumn{4}{|l|}{$\overline{\mathrm{GA}_{3} \text { effect }}$} \\
\hline $\mathrm{No} \mathrm{GA}_{3}$ & 9.0 & $1.15 \mathrm{a}$ & $7.9 \mathrm{a}$ \\
\hline $\mathrm{GA}_{3}$-treated & 9.1 & $1.20 \mathrm{~b}$ & $7.7 \mathrm{~b}$ \\
\hline \multicolumn{4}{|l|}{ Auxin effect } \\
\hline No auxin (hand-thinned) & $9.0 \mathrm{ab}$ & $1.18 \mathrm{ab}$ & $7.7 \mathrm{ab}$ \\
\hline 2,4-D & $9.1 \mathrm{~b}$ & $1.16 \mathrm{bc}$ & $8.0 \mathrm{~b}$ \\
\hline 2,4-DP & $9.2 \mathrm{~b}$ & $1.23 \mathrm{a}$ & $7.6 \mathrm{a}$ \\
\hline NAA & $8.8 \mathrm{a}$ & $1.12 \mathrm{c}$ & $8.0 \mathrm{~b}$ \\
\hline \multicolumn{4}{|l|}{ Analysis of variance } \\
\hline Parameter (df) & \multicolumn{3}{|c|}{----Proportion of total sum of squares $(\%)$---- } \\
\hline Year $(n=2)$ & $2.4^{\mathrm{NS}}$ & $54.0^{* *}$ & $60.1^{* *}$ \\
\hline $\mathrm{GA}_{3}$ application $(\mathrm{n}=1)$ & $0.4^{\mathrm{NS}}$ & $2.7^{*}$ & $1.4^{*}$ \\
\hline Auxin application $(\mathrm{n}=3)$ & $6.6^{\mathrm{NS}}$ & $6.5^{* *}$ & $3.3^{*}$ \\
\hline Residual $(\mathrm{n}=72)$ & 77.7 & 34.1 & 22.8 \\
\hline
\end{tabular}

${ }^{2}$ For each treatment, values within a column with different letters are statistically different $(P \leq 0.05)$

Ns, *, **Nonsignificant or significant at $P \leq 0.05$ or 0.01 , respectively.

EFFeCTS OF AUXIN APPLICATIONS ON FRUIT QUALITY. The fruit from the hand-thinned control and of the 2,4-D-treated-trees had thicker peels and greater peel weight and smaller segment weights, than the fruit treated with 2,4-DP and NAA (Table 6). On a fruit weight basis, the percentage of fruit juice in the handthinned trees was similar to the values found in the 2,4-DP and the NAA treatments, and slightly higher than in the 2,4-D treatment (Table 6). The differences in juice percentage among treatments were smaller when calculated on a segment weight basis. This percentage was lower in the 2,4-DP treatment than in the control and the NAA-treated fruit (Table 6).

The total soluble solid content in the juice was consistently lower in the NAA than in the 2,4-D- and the 2,4-DP-treated trees. These last two treatments did not differ from the hand-thinned controls (Table 7). On the other hand, the fruit from the 2,4-DP treatment had a higher acidity than the fruit from the rest of treatments. The TSS : TA ratio increased with the 2,4-D and the NAA applications as compared to the 2,4-DP-treated fruit, which did not differ from the hand-thinned control.

\section{Discussion}

In the conditions of our experimentation, the application of $\mathrm{GA}_{3}$ reduced generative shoot production but did not consistently increase the number of vegetative shoots or of leafy inflorescences (Table 1), which agrees with previous reports about other cultivars (reviewed by Davenport, 1990). An increase in vegetative shoot formation was found in satsuma trees when flower number was reduced to less than 15 per 100 nodes (Guardiola, 1981; Iwahori and Oohata, 1981), a figure well below the values found in our present experiments. Such a drastic reduction in flower number increased tree vigor but also reduced yield (Guardiola, 1988). In our study, the number of flowers per 100 nodes in the $\mathrm{GA}_{3}$-treated trees ranged from 35 to 60 , with average values of 44 (year 2) and 57 (year 4; Table 1). This reduction in flower formation increased significantly the number of leaves per flower, as may be easily calculated from the data in Table 1, but had no significant benefit on crop value as reported for other citrus species (Duarte et al., 1996; Guardiola et al., 1984). There are at least three reasons for this different behavior. The 2.5 -fold increase in yield reported in the 'Washington navel' orange by Guardiola et al. (1984) occurred when flowers per 100 nodes were reduced from 160 , a value well above those found in the present experiment, to 70-80. A further reduction in flower number had no significant effect on yield (Guardiola et al., 1984). In the present experiment, a significant increase in yield was also obtained in year 2 (Fig. 1), when the number of flowers per 100 nodes in the control trees was highest (103 on average, Table 1). Thus, it seemed that the potential beneficial effects of the $\mathrm{GA}_{3}$ applications were conditioned by flower number. Further, both in oranges (Sanz et al., 1987) and clementines (Guardiola et al., 1980), a GA 3 spray increased significantly leaf expansion and total leaf area in the tree, a response not found in 'Clausellina' satsuma (Table 2; R.V. Molina and J.L. Guardiola, unpublished results). This increase in leaf area may be a component of the invigorating effect of $\mathrm{GA}_{3}$ applications, as it may increase the photosynthetic capacity in the tree. In addition, a winter $\mathrm{GA}_{3}$ application has been reported to increase ovary size at anthesis both in navel orange (Guardiola et al., 1984) and 'Esbal' clementine (Duarte et al., 1996). This effect was not observed in 'Clausellina' satsuma (Table 1), which may be due to the much higher GA levels in the ovaries of satsuma mandarins at anthesis than in other Citrus species (Talón et al., 1992). In any case, the $\mathrm{GA}_{3}$ applied in the winter remained active in the tree for a long time, as demonstrated by the consistent effect on the acid content in the juice (Table 7).

The auxins used in our experiment have a direct enhancing effect on fruit growth, but differ in their effect on thinning (Guardiola and García-Luis, 2000). At the concentration we used, the application of 2,4-D at flowering has no direct thinning effect (Ortolá et al., 1997). Instead, the faster fruitlet growth rate resulting from this application causes a stronger intersink competition among the developing fruitlets, which increases thinning several weeks after 2,4-D application (Duarte et al., 1996). On the other hand, at the stage of development at which these auxins were applied, both 2,4-DP and NAA induced ethylene synthesis, which resulted in an immediate thinning effect (Guardiola and García-Luis, 2000). In this work we used a 2,4-DP concentration $\left(50 \mathrm{mg} \cdot \mathrm{L}^{-1}\right)$, which proved optimal in previous studies (Agustí et al., 1992; Vanniere and Arcuset, 1989). The concentration of NAA used by us was suboptimal in terms of the enhancement of fruit growth, but we tried to prevent excessive thinning (Ortolá et al., 1991). Despite the different action mechanisms, in our experiment the three auxin applications were equally effective to reduce fruit number and to increase fruit size, thus enhancing crop value above the hand-thinned controls (Tables 3 and 5). The differences among the auxins were within the experimental error, and we could not confirm the reported higher effectiveness of the auxin 2,4-DP to increase fruit size and crop value (Agustí et al., 1992). On the other hand, an advantage of the 2,4-D application as compared to other auxins results because of the lower cost of this chemi$\mathrm{cal}$, and the smaller influence of the timing of its application on the response as demonstrated in other cultivars (Guardiola and García-Luis, 2000).

Apart from their effects on fruit size, the auxins had only a marginal effect on fruit quality when fruit of the same size was compared (Tables 6 and 7). The most salient features were the higher acid contents in the 2,4-DP treatment, and the higher peel proportion in the 2,4-D application. This different effect on peel 
proportion depends on the time of application, and is not related to the nature of the auxin molecule. It has been demonstrated that auxin applications shortly after flowering enhance the growth of both the mesocarp and the juice vesicles; while applied at a later stage of development, they have a selective effect on the growth of the juice vesicles (Guardiola et al., 1993). While the greater peel weight in the 2,4-D-treated (and the control) trees reduced the percentage of juice on a fruit-weight basis, it did not affect the percentage of juice in the edible part of the fruit; i.e., the segments (Table 7). This is relevant as this parameter determines the perception of fruit juiciness by the consumer.

In conclusion, while the winter $\mathrm{GA}_{3}$ applications showed no beneficial effects on crop value in 'Clausellina' satsuma, a significant benefit was obtained from the auxin applications every year, as they increased the amount of first-grade fruit without presenting a significant interaction with the year effect (Table 4). It must be noted however that the year-to-year variations had a greater impact on fruit size and earliness than the auxin applications. Therefore, the comparison of auxin effects using data from different years without appropriate common treatments, as sometimes is performed, may lead to wrong conclusions on their relative effectiveness.

\section{Literature Cited}

Agustí, M., V. Almela, M. Aznar, J. Pons, and M. El-Otmani. 1992. The use of 2,4-DP to improve fruit size in Citrus. Proc. Intl. Soc. Citricult. $1: 423-427$

Agustí, M., V. Almela, M. Juan, E. Primo-Millo, I. Trenor, and S. Zaragoza. 1994. Effect of 3,5,6-trichloro-2-pyridil-oxyacetic acid on fruit size and yield of "Clausellina" mandarin (Citrus unshiu Marc.). J. Hort. Sci. 69:219-223.

Davenport, T.L. 1990. Citrus flowering. Hort. Rev. 12:349-408.

Duarte, A.M.M., D.T.G. Trindade, and J.L. Guardiola. 1996. Thinning of Esbal clementine with 2,4-dichlorophenoxyacetic acid. Influence on yield, fruit size and fruit quality. Proc. Intl. Soc. Citricult. 2:1069-1071.

Goldschmidt, E.E. and S.P. Monselise. 1972. Hormonal control of flowering in citrus and some other woody perennials, p. 758-766. In: D.J. Carr (ed.). Plant growth substances. Springer Verlag, Berlin.

Guardiola, J.L. 1981. Flower initiation and development in citrus. Proc. Intl. Soc. Citricult. 2:242-246.

Guardiola, J.L. 1988. Factors limiting productivity in citrus: A physiological approach. Proc. Intl. Soc. Citricult. 1:381-394.
Guardiola, J.L., M. Agustí, J.M. Barberá, and F. García-Marí. 1980. Influencia de las aplicaciones de ácido giberélico durante la brotación en el desarrollo de los agrios. Revista de Agroquímica y Tecnología de Alimentos 20:139-143.

Guardiola, J.L., M.T. Barrés, C. Albert, and A. García-Luis. 1993. Effect of exogenous growth regulators on fruit development in Citrus unshiu. Ann. Bot. 71:169-176.

Guardiola, J.L. and A. García-Luis. 2000. Increasing fruit size in citrus. Thinning and stimulation of fruit growth. Plant Growth Regulat. 31:121-132.

Guardiola, J.L., F. García-Marí, and M. Agustí. 1984 Competition and fruit set in the Washington navel orange. Physiol. Plant. 90:27-36.

Guardiola, J.L., C. Monerri, and M.Agustí. 1982. The inhibitory effect of gibberellic acid on flowering in citrus. Physiol. Plant. 55:136-142.

Guardiola, J.L., S. Zaragoza, R. Bono, and F. Medina. 1973. Características del fruto y de la planta de cinco mutaciones de satsuma. Actas Congreso Mundial Citricultura 2:65-76.

Iwahori, S. and J.T. Oohata. 1981. Control of flowering of satsuma mandarins (Citrus unshiu Marc.) with gibberellin. Proc. Intl. Soc. Citricult. 1:247-249.

Jiménez-Cuesta, M., C. Cuquerella, and J.M. Martínez-Jábega. 1981. Determination of a colour index for citrus fruit degreening. Proc. Intl. Soc. Citricult. 2:750-753.

Moss, G.I. 1970. Chemical control of flower development in sweet orange (Citrus sinensis L. Osbeck). Austral. J. Agr. Res. 21:233-242.

Organisation de Coopération et Développement Économique. 1971. Normalisation Internationale des fruits et légumes. Agrumes. OCDE. Paris

Ortolá, A.G., C. Monerri, and J.L. Guardiola. 1991. The use of naphthalene acetic acid as a fruit growth enhancer in Satsuma mandarin: A comparison with the fruit thinning effect. Scientia Hort. 47:15-25.

Ortolá, A.G., C. Monerri, and J.L. Guardiola. 1997. Fruitlet age and inflorescence characteristics affect the thinning and the increase in fruitlet growth rate induced by auxin applications. Acta Hort. 463:501-508.

Sanz, A., C. Martínez Cortina, and J.L. Guardiola. 1987. The effect of the fruit and exogenous hormones on leaf expansion and composition in Citrus. J. Exp. Bot 38:2033-2042.

Talón, M., L. Zacarías, and E. Primo Millo. 1992. Gibberellins and parthenocarpic ability in developing ovaries of seedless mandarins. Plant Physiol. 99:1575-1581.

Vanniere, H. and P. Arcuset. 1989. Amélioration du calibres des Clémentines en Corse par l'employ du dichlorprop. Fruits 44:393-400.

Zaragoza, S., I. Trénor, and E. Alonso. 1990. Influencia del aclareo sobre el calibre de los frutos en la Satsuma Clausellina. Actas I Congreso Ibérico Ciencias Hortícolas 3:113-118. 